Aletria, Belo Horizonte, v. 28, n. 3, p. 123-131, 2018

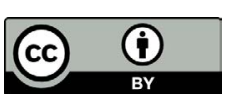

\title{
Acts of Literature II
}

Luiz Fernando Ferreira Sa

Universidade Federal de Minas Gerais, Belo Horizonte, Minas Gerais / Brasil saluiz18@gmail.com

Miriam Piedade Mansur Andrade

Universidade Federal de Minas Gerais, Belo Horizonte, Minas Gerais / Brasil mandrade1@gmail.com

Stephen Jay Greenblatt is a North-American Shakespearean, literary historian, and author. He is John Cogan University Professor of the Humanities at Harvard University. He is the general editor of The Norton Shakespeare (2015) and the general editor of The Norton Anthology of English Literature.

Greenblatt is one of the founders of New Historicism, a set of critical practices that he often refers to as "cultural poetics"; his works have been influential since the early 1980s, when he introduced the term. Greenblatt has written and edited numerous books and articles relevant to New Historicism, the study of culture, Renaissance studies and Shakespeare studies and is considered to be an expert in these fields. $\mathrm{He}$ is also co-founder of the literary-cultural journal Representations, which often publishes articles by new historicists. One of his most popular works is Will in the World, a biography of Shakespeare that was on The New York Times Best Seller List. He won the Pulitzer Prize for General Non-Fiction in 2012 and the National Book Award for Nonfiction in 2011 for The Swerve: How the World Became Modern.

This interview was carried out via e-mail in March, 2018. 
Luiz Fernando Ferreira Sá and Miriam Piedade Mansur Andrade: Aletria, a journal of Literary Studies of the Graduate Program in Letters at the Federal University of Minas Gerais, devotes this issue to contributions that offer a critical or theoretical reading of early modern English authors (c. 1453-1789), who wrote in a period of unprecedented national and international political, cultural, social, religious, and scientific changes. First and foremost, we would like to know how eclectic New Historicism is and the extent to which New Historicism sheds new light on early modern literature. In addition, what other theoretical voices do you use in your conversation, so to speak, with Michel Foucault?

Greenblatt: For better or worse, from its inception New Historicism was madly eclectic. It grew out of my impatience with what I perceived as the narrowness of the American high formalism in which I was trained. But it also grew out of my frustration with the Marxist literary criticism - primarily Lukács and Althusser - to whom I had initially turned as an alternative to Wimsatt, Brooks, and the like. I wanted the whole field of early modern culture to be at play, not only the literary masterpieces but also the theology, the travel narratives, the police reports, the apocalyptic fantasies of half-mad prophets, and the like. Foucault was immensely helpful in escaping from the superstructure/base dichotomy, but so too were Walter Benjamin, Michel de Certeau, Louis Marin, Clifford Geertz, and many others.

LFFS and MPMA: In Renaissance Self-Fashioning (1980) you introduce the term self-fashioning to designate the process of constructing one's identity and public persona according to a set of socially acceptable standards. To what extent is self-fashioning free from the dangers of self-portrayals of powerful men entangled in their own fantasies? Furthermore, how does a critic traffic with inner intimations of unreality or human absurdity and produce sound, academic analyses?

Greenblatt: Self-fashioning is never - can never be - free from the dangers of delusional or self-interested self-portrayals of the figures it studies: those self-portrayals are precisely the raw materials in which it traffics. And if by "sound, academic analyses," you mean impeccably objective empirical studies untouched by either the fantasies of the past or the longings of the present, then it would be better, I think, to find 
a different topic in which to interest oneself. But interesting analyses obviously need to do more than to recapitulate whatever identities were shaped by early modern figures or to insist only on our own alternative accounts of the self. The whole challenge is to bring the two, often antithetical spheres into a living relationship with one another.

LFFS and MPMA: In Shakespearean Negotiations: The Circulation of Social Energy in Renaissance England (1988) you open the first chapter by stating that "I began with the desire to speak with the dead." Can the dead speak? And if the answer is positive, how does one lend an ear to the dead so that one speaks with the dead instead of speaking for the dead?

Greenblatt: Unless we have the insane idea that the world was created at the same moment that we were born, we know that the dead do indeed speak to us all the time. Their voices (and their dreams and desires and fear) are everywhere - in the landscapes in which we find ourselves, the buildings we inhabit, the books we read, and above all the languages that we ourselves use. The challenge, though we do not always recognize it, is at least as much to speak to the dead in our own original voices (whatever they may be) as it is to hear the dead speak.

LFFS and MPMA: Also with respect to the first chapter of Shakespearean Negotiations you felt appropriate to issue certain caveats: "For the circulation of social energy by and through the stage was not part of a single coherent, totalizing system. Rather it was partial, fragmentary, conflictual; elements were crossed, torn apart, recombined, set against each other; particular social practices were, magnified by the stage, others diminished, exalted, evacuated. What then is the social energy that is being circulated? Power, charisma, sexual excitement, collective dreams, wonder, desire, anxiety, religious awe, free-floating intensities of experience: in a sense the question is absurd, for everything produced by the society can circulate unless it is deliberately excluded from circulation. Under such circumstances, there can be no single method, no overall picture, no exhaustive and definitive cultural poetics." You then went on to spell out the "different types of negotiation: in the histories, a theatrical acquisition of charisma through the subversion of charisma; in the comedies, an acquisition of sexual excitement through the staging of transvestite friction; in the tragedies, an acquisition of religious power 
through the evacuation of a religious ritual; and in the romances, an acquisition of salutary anxiety through the experience of a threatening plenitude." Are we right to affirm, then, that the conduit for the circulation of social energy is a kind of critique of the relationship between meaning (in abstract) and social meaning (in material terms), a kind of reading of texts with an ear to what runs counter to the structural unity or intended sense of a particular meaning, and/or a kind of exposure of the object of meaning as irreducibly complex, unstable, or impossible?

Greenblatt: Not impossible, but always provisional. And yes, the key is to understand that there never is a perfectly unified field of meaning in any significant sphere of social life, including the life of literature. The energy always flows across obstacles; indeed, the obstacles intensify the energy. I have learned to be deeply wary of any assumption that in this period "everyone believed" or "no one could have thought" this or that. It usually turns out that someone or other was in fact doubting what supposedly could not be doubted or thinking what supposedly could not be thought.

LFFS and MPMA: In Learning to Curse: Essays in Early Modern Culture (1990) do the collected essays form the silhouettes of a kind of cultural Bildung? Or, alternatively, does self-cultivation create boundaries and margins that are vital to its existence?

Greenblatt: I have not returned to those essays for some time, but I think that the only Bildung they reliably delineate is my own - that is, they display whatever was catching my attention in the 1980s and exciting my desire to write, often at a feverish pace.

LFFS and MPMA: Is Marvelous Possessions: The Wonder of the New World (1991) a study of the ways in which Europeans of the early modern period represented non-European peoples and took possession of their lands, a return to the circulation of social energy much like in Shakespearean Negotiations, this time around social energy extended to cultural energy? Is this book, generally speaking, an account of the acquisition of territory through the subversion of possession, an acquisition of the odd and exotic through the staging of the friction surrounding alterity, an acquisition of power over the "newly-found" 
lands through the evacuation of their peoples, and, finally, an acquisition of salutary anxiety through the experience of a threatening plenitude?

Greenblatt: I had not conceived of Marvelous Possessions in these terms, though your suggestion is an interesting one. My book is poised, I think, between a vision akin to the 1977 film Close Encounters of the Third Kind - in which the threat of intergalactic violence is dissipated by the overwhelming experience of mutual wonder - and the sentiment satirically expressed by the popular anti-Vietnam war bumper sticker: "Join the army; travel to exotic, distant lands; meet exciting, unusual people and kill them." I wanted to know how the primal emotion of the marvelous was turned into the desire to possess and exploit.

LFFS and MPMA: In Hamlet in Purgatory (2002) you seem to return to issues related to boundaries (life and death) and to the desire, if not to speak with the dead, to analyze how a famous character in literature (Hamlet) had encounters with the afterlife. What are your views on the way power can provoke nightmares, generate strange images, and create haunting specters? Are there "plagues" (general cultural swerves) associated with, or borne out by, the specter(s) haunting Hamlet?

Greenblatt: From the ancient world all the way through the Renaissance and beyond, people shared a widespread belief in the significance of dreams - their sensitivity to menace, their alertness to hidden desire, and even their prophetic power. In Richard III George, duke of Clarence, cannot allow into his conscious mind the murderous hostility of his brother Richard, duke of Gloucester, but his dream registers this hostility and anticipates his own fate. From the seventeenth-century on, Western culture gradually weaned itself of faith in dreams, but there has been a high price for this disillusionment.

LFFS and MPMA: Will in the World: How Shakespeare Became Shakespeare (2004) - a pun and a tautological subtitle. Are you ultimately teaching us that the divide between fact and fiction is an untruth, that there is only the fictions we create (even if to the historian or to the new historicist critic the point of departure is material - letters, documents, the concrete archival records -, interpretation is needed after all)? 
Greenblatt: Despite what I just said about the prophetic power of dreams, I hope not. I believe that the divide between fiction and truth is important - without it, we are in the power of every lying politician who gets his hands on the mechanisms of control. But the truth is almost never simply there for the taking. There is no escape from interpretation. In Will in the World, in any case, I tried to base every one of my claims on at least some shred of documentary evidence or at least logical presumption, independent of the plays and poems themselves. (By logical presumption, I mean simply the fact that there must have been some specific moment in which Shakespeare saw a play for the first time, or one particular day in which he first arrived in London.) I marked my speculations as speculations, and I abjured, with regret, the claim that Shakespeare's wife Anne must have cheated on him - the basis for Joyce's brilliant biographical fantasia - on the grounds that there was not even a trace of independent evidence.

LFFS and MPMA: In Shakespeare's Freedom (2010) you openly state: "My interest in this book is in the ways that Shakespeare establishes and explores the boundaries that hedge about the claims of the absolute. My focus in the chapters that follow is on four underlying concerns to which Shakespeare's imagination was drawn consistently and across the multiple genres in which he worked. These concerns are beauty Shakespeare's growing doubts about the cult of featureless perfection and his interest in indelible marks; negation - his exploration of murderous hatred; authority - his simultaneous questioning and acceptance of the exercise of power, including his own; and autonomy - the status of artistic freedom in his work." Boundaries and the ways one images them into being, or imagines them, take frontstage: beauty, negation, authority, and autonomy. Are those terms specters returning from the undead and, therefore, "destructuring" terms exposing our mendacity when it comes to ontology, epistemology, ethics, aesthetics, and hermeneutics? How free was Shakespeare and, for that matter, how is freedom the new index for genius?

Greenblatt: Shakespeare's freedom had its limits - that much is cleardue to the apparatus of state control and the demands of the public theater as a commercial enterprise. But it was greater than it might at first seem: 
this is a playwright who has a character stand up before an audience of 2-3 thousand spectators, day after day, and declare that "a dog's obeyed in office." If you said that in a tavern, you could have your ears cut off and your nose sliced in two. How did Shakespeare get away with it? The words are spoken by the mad King Lear.

LFFS and MPMA: Concerning The Swerve: How the World Became Modern (2011), to what extent is it a response to Lucretius' On the nature of things? How would you, after six years of its publication, characterize the "counter" in this reading as counter-signature? Furthermore, is the swerve in the title catachrestic?

Greenblatt: The "swerve" in my title is simply a perfectly plausible English translation of Lucretius's clinamen, the term he uses to describe the miniscule shift in direction that causes atoms (the semina rerum) to collide with one another. But, of course, "simply" is not entirely true: the word is meant to gesture toward a series of historical or cultural or intellectual shifts, for example, the one that followed from Poggio Bracciolini's recovery of the manuscript of Lucretius and its return to circulation.

LFFS and MPMA: The Rise and Fall of Adam and Eve (2017). If, on the one hand, your reader may gather that you contend that the steady accumulation of philological, anthropological, biological, and geological knowledge has made the Genesis story no longer tenable, except as fiction; on the other hand, your reader may be tempted to recall your desire to speak with the dead, to respond to diverse specters, and conclude that you embraced fiction as you read its "aporias": "Adam and Eve had become so real in Milton's imagination that they began to crack open the whole theological apparatus that brought them into being." Do you actually leave the reader in doubt as to whether science has won the intellectual debate? To put the question in a more provocative way: are you an Enlightenment realist or a post-structuralist intellectual?

Greenblatt: Ordinary people live on multiple tracks - it is clearly the case that the large number of Americans who profess to believe in the literal truth of the story of Adam and Eve do not reject modern science. They certainly accept the outcomes of that science, including medical 
and technological innovations that are built upon genetics and physics that are utterly incompatible with the Genesis story. Why don't they live more coherently? Because they are not compelled to, and they find the Adam and Eve story, in Lévi-Strauss' phrase, "good to think with." I am not someone who doubts the modern scientific account of the world (though I understand very well that someday it too will seem archaic and almost fiction-like), and I am not someone who professes to believe in the literal truth of Genesis. But I do believe in the power of literature and art. And in literature and art there is absolutely no room for either utter disillusionment or an Enlightenment narrative of progress.

LFFS and MPMA: From Cultural Mobility: A Manifesto (2009): "Although in the past twenty years or so many academic disciplines have formally embraced ideas of 'cultural mobility,' they have for the most part operated with tunnel vision: the times and places in which they see significant mobility occurring remain strictly limited; in all other contexts, they remain focused on fixity." From Hamlet (1603): "The time is out of joint - O cursèd spite, That ever I was born to set it right!" How does an intellectual in the contemporary world go about proposing new joints, if not for time, for the world? How does an intellectual in our present situation assess cultural mobility with a view to giving an afterlife to such old and degenerated joints? What revolutions are needed in the contemporary world that would produce joints conducive to strengthening the articulations or to heightening mobility?

Greenblatt: You are asking me this question at moment in which borders are closing, and a rising tide of nationalism in my country and throughout the world is calling mobility into question. I wish I had an answer to your question, but I do not. I once thought that the coming environmental disaster at a global scale would at least bring humanity together in a shared attempt to save itself. I'm not sure any longer. I fear it will be dog against dog. But I am all the more committed to a politics that embraces crossing of boundaries. 


\section{References}

GREENBLATT, Stephen et al. Cultural Mobility: A Manifesto. Cambridge: Cambridge University Press, 2009.

GREENBLATT, Stephen. Hamlet in Purgatory. Princeton: Princeton University Press, 2002.

GREENBLATT, Stephen. Learning to Curse: Essays in Early Modern Culture. London: Harvard University Press, 1990.

GREENBLATT, Stephen. Marvelous Possessions: The Wonder of the New World. Chicago: University of Chicago Press, 1992.

GREENBLATT, Stephen. Renaissance Self-Fashioning: From More to Shakespeare. Chicago: University of Chicago Press, 1980.

GREENBLATT, Stephen. Shakespeare's Freedom. Chicago: University of Chicago Press, 2010.

GREENBLATT, Stephen. Shakespearean Negotiations: The Circulation of Social Energy in Renaissance England. Berkeley: University of California Press, 1989.

GREENBLATT, Stephen. The Rise and Fall of Adam and Eve. New York: W. W. Norton, 2017.

GREENBLATT, Stephen. The Swerve: How the World Became Modern. New York: W. W. Norton, 2011.

GREENBLATT, Stephen. Will in the World: How Shakespeare Became Shakespeare. New York: W. W. Norton, 2005. 